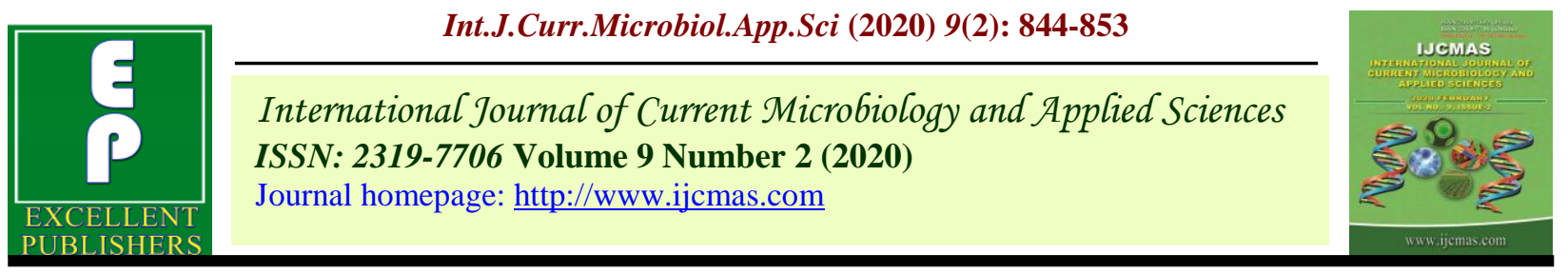

Original Research Article

https://doi.org/10.20546/ijcmas.2020.902.102

\title{
Variability in Morphological and Cultural Characters of Different Isolates of Fusarium oxysporum f.sp. lini
}

\author{
Narinder Pal" and Ashok Kumar \\ Department of Plant Pathology, CSK HPKV, Palampur-176062, India \\ *Corresponding author
}

\section{A B S T R A C T}

Keywords

Linseed, Fusarium oxysporum f.sp. lini, microconidia, macroconidia

Article Info

Accepted:

08 January 2020

Available Online:

10 February 2020
Thirty-five isolates of Fusarium oxysporum f.sp. lini were isolated from available diseases plant samples. Morphological studies of these isolates revealed that macroconidia were straight; spindle as well as sickle shaped. In macroconidia, average length varied from $11.26 \mu \mathrm{m}$ in Foli-9 to $38.33 \mu \mathrm{m}$ in Foli-13 with 1-5 septa and average breadth varied from $1.95 \mu \mathrm{m}$ in Foli-22 to $3.16 \mu \mathrm{m}$ in Foli-13.In microconidia, average length varied from $4.45 \mu \mathrm{m}$ in Foli-9 to $11.19 \mu \mathrm{m}$ in Foli13 with $0-1$ septa and average breadth of varied from $1.75 \mu \mathrm{m}$ in Foli-2 to $3.01 \mu \mathrm{m}$ in Foli-29. Six isolates showed cottony white, 12 isolates showed pale white and17 isolates showed purplish white growth of culture. Eleven isolates were fast growing, 21 isolates were medium growing and 3 isolates were slow growing.

\section{Introduction}

Linum usitatissimum L. commonly known as linseed or flaxseed is an ancient oilseed and fiber crop. India, it is grown mainly for seed, used for extracting oil and it is such a valuable crop that every part of the plant has specific economic importance (Gill, 1967). Among the fungal diseases of linseed, wilt is a major constraint responsible for low production and productivity along with rust and powdery mildew (Kishore et al., 2011).

Linseed wilt incited by Fusarium oxysporum f.sp. lini (Bolly) Snyder and Hansen was first reported by Luggar (1890) from Minnesota, USA. Bolley and Manns (1932) isolated the
Fusarium oxysporum. f.sp. lini (Bolly) from disease infected seeds for the first time by growing it on glucose agar medium in vitro in petriplates. Kommedahl et al., (1970) identified that isolates of Fusarium oxysporum f.sp. lini vary in: 1) morphology, with respect to the amount and type of sporulation, production of different types of conidia, size and number of septa and pigment production on growth media; 2) physiology, rate and type of growth on substrates and in host; 3) environmental preferences, antibiotic capabilities; and 4) pathogenicity. Therefore, it is considered an ideal pathogen to demonstrate diversity within a species. 


\section{Materials and Methods}

\section{Collection, isolation and purification of Fusarium oxysporum f.sp. lini}

Linseed plants naturally infected and showing typical wilt symptoms were collected from farmer's fields from 29 locations in district Kangra and Mandi of Himachal Pardesh and brought to the laboratory. At each field, three observations on total number of linseed plants in $1 \mathrm{~m}^{2}$ area and total wilted plants in the sampling area were recorded to calculate per cent disease incidence of wilt in the field by using formula (Mayee and Datar, 1986) as detailed below.

Per cent Disease Incidence $=$ Number of plants infected by wilt / Total number of plants x 100

Wilt incidence of five fields at each location was recorded to calculate the average disease incidence of the location. Linseed plants showing typical wilting symptoms were collected in separate paper bags and brought to the laboratory for isolation of Fusarium oxysporum f.sp. lini from the diseased plant parts. A total of 25 isolates were obtained from the isolation of diseased plant samples of these 29 locations. Some additional samples were procured from the other major linseed growing parts of India. The roots and stems of infected plants were washed in tap water to remove adhering soil particles, if any and root bark was removed before isolation to avoid contamination.

The roots and stems were split open and small bits (size $2.5 \mathrm{~cm}$ ) were cut with sterilized sharp blade. These bits were then disinfected with $0.1 \%$ solution of mercuric chloride for one or two minutes, then washed thoroughly in sterile distilled water thrice to remove the traces of mercuric chloride, dried in sterile blotter paper and aseptically transferred on
PDA in petriplate, and incubated at $25 \pm 2{ }^{\circ} \mathrm{C}$ for a week. Fungus growth in plate was examined and then sub-cultured on PDA slants. By frequent subculturing, it was purified and maintained on PDA slants for further studies. A total of 35 isolates of pathogen were isolated from available samples and were designated as Foli-1 to Foli-35.

The pure culture of fungus was obtained by adopting single spore techniques as described by Choi et al., (1999). On the basis of cultural and morphological characteristics i.e. size of micro and macro conidia, number of septa, colony colour, colony growth and pigmentation etc., the test pathogen was identified as Fusarium oxysporum f.sp. lini by comparing with the monograph of Fusarium oxysporum f.sp. lini given by Booth (1971) and described by Burgess et al., (1994).

\section{Morphological and cultural characteristics}

Thirty-five isolates of Fusarium oxysporum f.sp. lini were further studied for their morphological characters viz., size of macroconidia, microconidia \& septation, $5 \mathrm{~mm}$ diameter disc of mycelia of each isolates were taken from the actively growing culture and placed upside down centrally on $90 \mathrm{~mm}$ petridish containing solidified PDA medium and the inoculated plates were incubated at 25 $\pm 2^{\circ} \mathrm{C}$ for 9 days. Each plate was replicated three times. To record size and septation of macroconidia \& micrconidia a clear slide was prepared from 9 days old culture, stained with cotton blue and observed under the calibrated compound microscope. The length and breadth of twenty macroconidia and microconidia for each of three replications were measured. Cultural characteristics such as colony colour, pigmentation and colony diameter after 9 days of inoculation were also recorded for all the 35 isolates. 


\section{Results and Discussion}

The data in the Table 1 represents that wilted plant samples were collected from six linseed growing blocks of district Kangra viz., Rait, Kangra, Bhawarna, Nagrota Bagwan, Sulah and Baijnath. The average disease incidence of the 5 locations in block Rait varied from 8.22 to 35.00 per cent, at 2 locations of block Knagra average disease incidence was recorded 32.29 and 40.75 per cent, at 3 locations of block Nagrota Bagwan average disease incidence varied from 11.30 to 42.00 per cent and at 4 locations of block Baijnath it varied between 12.15 to 28.95 per cent.

Whereas at single locations of block Bhawarna and Sullah the average disease incidence was recorded 10.25 and 32.55 per cent. Sixteen isolates were obtained from the isolation of these samples and designated as: Foli-1 to Foli-16. Similarly, disease samples were also collected from the linseed fields of Chauntra and Drang blocks of district Mandi and the average disease incidence in these blocks was recorded 9.50 to 22.45 per cent and 7.36 to 48.20 per cent, respectively.

Nine isolates were obtained from the isolation of diseased roots and other plant parts collected from linseed fields of these two blocks of district Mandi and designated as: Foli-17 to Foli-25. Table 1 also shows occurrence of Fusarium oxysporum f.sp. lini in wilted plant samples procured from other ten linseed growing parts of India i.e. Raipur (Chhattisgarh), Faizabad (Uttar Pradesh), Gorakhpur (Uttar Pradesh), Kanpur (Uttar Pradesh), Kota (Rajasthan), Kaul (Haryana), Ludhiana (Punjab), Gurdaspur (Punjab), Mukeriyan (Punjab) and Jammu (Jammu \& Kashmir). Ten isolates were obtained from the isolation of diseased roots and other plant parts of linseed and designated as: Foli-26 to Foli-35.

\section{Variability in morphological characters}

Morphological studies revealed variation in size of microconidia, macroconidia and number of septa among thirty five isolates of Fusarium oxysporum f.sp. lini. The results presented in Table 2 indicate that all isolates of Fusarium oxysporum f.sp. lini used in study varied significantly in their morphological and cultural characteristics on PDA (Plate a). Macroconidia were straight; spindle as well as sickle shaped. Table 2 showed variation in size of macroconidia. The average length of macroconidia varied from 11.26 $\mu \mathrm{m} \mu \mathrm{m}$ in Foli-9 to $38.33 \mu \mathrm{m}$ in Foli13. The average breadth of macroconidia varied from $1.95 \mu \mathrm{m}$ in Foli-22 to $3.16 \mu \mathrm{m}$ in Foli-13. While, number of septa in macroconida varied from 1-5. Based on the length of macroconidia, the isolates were grouped into two categories as large (above $30 \mu \mathrm{m}$ ) and small (up to $30 \mu \mathrm{m}$ ) macroconidia as given by Dubey et al., (2010). Four Isolates Foli-11, Foli-13, Foli-20, \& Foli-30 showed above $30 \mu \mathrm{m}$ length of conidia and categorized as large macroconidia and remaining 31 isolate showed up to 30 length of conidia and categorized as small macroconidia. Table 2 also shows that variation was also recorded in size of microconidia. The average length of microconidia varied from $4.45 \mu \mathrm{m}$ in Foli-9 to $11.19 \mu \mathrm{m}$ in Foli-13. The average breadth of microconidia varied from $1.75 \mu \mathrm{m}$ in Foli-2 to $3.01 \mu \mathrm{m}$ in Foli-29. The number of septa varied from 0-1. In similar studies Saharan and Mehta (2002) stated that both micro and macroconidia were produced by isolates of Fusarium oxysporum f.sp. lini.

The average size of microconidia ranged from $4.8-14.4$ x $2.2-4.8 \mu \mathrm{m}$ and in macroconidia the average size ranged from $21.0-53.0 \times 2.4$ - $5.6 \mu \mathrm{m}$. Kriplani et al., (2018) studied cultural, morphological and pathogenic variability of Fusarium oxysporum f.sp. pisi. 
The mycelia colour of the isolates varied from white to light pink, purple and pale yellow colour. The radial growth of the isolates ranged from $5.4 \mathrm{~cm}$ to $8.9 \mathrm{~cm}$ at 8 days. The size of macroconidia ranged from $11.6 \times 3.1$ to $25.2 \times 6.2 \mu \mathrm{m}$ and size of microconidia ranged from $3.02 \times 2.1 \mu \mathrm{m}$ to $9.2 \times 5.6 \mu \mathrm{m}$.

The number of septation of macroconidia was mostly 2-3 \& microconidia in most of the isolates were having no septum. Dubey et al., (2010) observed isolates of $F$. oxysporum f.sp. ciceris to vary with respect to their conidia size. Microconidia varied from 5.1-12.8 x 2.5$5.0 \mu \mathrm{m}$ in size, whereas macroconidia were from 16.5-37.9 $\times 4.0 \times 5.9 \mu \mathrm{m}$ with $1-5$ septations most commonly with 2-3 septate conidia. Gupta et al., (2011) noticed morphological variation among isolates of $F$. oxysporum f.sp. pisi.

The size of microconidia varied from $3.16 \mathrm{x}$ $3.16 \mu \mathrm{m}$ (isolate I19) to $9.13 \times 5.44 \mu \mathrm{m}$ (isolate I7) whereas macroconidial size varied from $11.77 \times 3.16 \mu \mathrm{m}$ (isolate I19) to $24.60 \mathrm{x}$ $5.91 \mu \mathrm{m}$ (isolate I7). All isolates formed chlamydospores on PDA medium except isolate I2. Chlamydospores size varied from $6.85 \times 6.15 \mu \mathrm{m}$ (isolate I4) to $13.70 \times 10.18$ $\mu \mathrm{m}$ (isolate I5).

\section{Variability in cultural characteristics}

Table 3 shows that the colony colour of the 35 isolates varied from cottony white to purplish white. Six isolates viz., Foli-1, Foli-9, Foli-10, Foli-12, Foli-21 \& Foli-27 showed cottony white growth. 12 isolate viz., Foli-3, Foli-8, Foli-13, Foli-15, Foli-16, Foli-18, Foli-22, Foli-23, Foli-29, Foli-31, Foli-33 \& Foli-34 showed pale white and17 isolates viz., Foli-2, Foli-4, Foli-5, Foli-6, Foli-7, Foli-11, Foli-14, Foli-17, Foli-19, Foli-20, Foli-24, Foli-25, Foli-26, Foli-28, Foli-30, Foli-32 \& Foli-34 showed purplish white growth of culture. The isolates also varied in their pigmentation from without any pigmentation in 9 isolates viz., Foli-3, Foli-4, Foli-12, Foli-13, Foli-15, Foli21, Foli-27, Foli-31 \& Foli-35 to light pinkish in 6 isolates viz., Foli-1, Foli-5, Foli-7, Foli17, Foli-20 \& Foli-34, purplish in 17 isolates viz., Foli-2, Foli-6, Foli-9, Foli-10, Foli-14, Foli-16, Foli-18, Foli-19, Foli-22, Foli-23, Foli-24, Foli-26, Foli-28, Foli-29, Foli-30, Foli-32 \& Foli-33 and brownish in 3 isolates viz., Foli-8, Foli-11 \& Foli-25 (Plate b). Similarly, Nath et al., (2017) observed that Fusarium oxysporum f.sp. ciceri exhibited variations in colony characteristics such as color, shape, margin and texture. Colony colors were purplish white, whitish orange, creamy white, cottony white. While, Prameela et al., (2005) observed variation in substrate pigmentation in isolates of $F$. oxysporum f.sp. carthami.

The colony diameter of the isolates after 9 days of incubation showed that the fastest growing isolates were Foli-11, Foli-25 and Foli-30 with $90 \mathrm{~mm}$ of growth. All the isolates were grouped in to 3 groups i.e. fast growing (above $80 \mathrm{~mm}$ growth), medium growing (70-80 $\mathrm{mm}$ growth) and slow growing (below $70 \mathrm{~mm}$ growth) as described by Wagh (2009). Eleven isolates viz., Foli-2, Foli-6, Foli-10, Foli-11, Foli-13, Foli-25, Foli-29, Foli-30, Foli-32, Foli-33 and Foli-35 were fast growing. While 21 isolates viz., Foli-1, Foli-3, Foli-4, Foli-5, Foli-7, Foli-8, Foli-9, Foli-12, Foli-14, Foli-15, Foli-16, Foli-17, Foli-19, Foli-20, Foli-21, Foli-22, Foli-23, Foli-24, Foli-28, Foli-30 \& Foli-34 were medium growing and 3 isolates viz.,

Foli-18, Foli-26 and Foli-27 were slow growing. Wagh (2009) also observed variability in growth among different isolates of Fusarium oxysporum f.sp. lini. In their study one isolate was recorded as fast growing $(82.00 \mathrm{~mm})$ while remaining 5 isolates showed moderate mycelial growth on PDA ranging from $71.60 \mathrm{~mm}$ to $78.10 \mathrm{~mm}$ 
Table.1 Occurrence of Fusarium oxysporum f.sp. lini in the plant samples collected from different linseed fields of Himachal Pradesh and procured from other linseed growing parts of India

\begin{tabular}{|c|c|c|c|}
\hline Sr. no. & $\begin{array}{l}\text { Location of sample collection } \\
\text { District Kangra:- }\end{array}$ & $\begin{array}{l}\text { Name of } \\
\text { Isolate }\end{array}$ & $\begin{array}{c}\text { Average disease } \\
\text { incidence }(\%) \text { at } \\
\text { the location }\end{array}$ \\
\hline 1. & Parei (Block Rait) & Foli-1 & 35.00 \\
\hline 2. & Rait (Block Rait) & Foli-2 & 08.22 \\
\hline 3. & Rajol (Block Rait) & Foli-3 & 25.15 \\
\hline 4. & Parsail (Block Rait) & Foli-4 & 19.62 \\
\hline 5. & Shahpur (Block Rait) & Foli-5 & 12.50 \\
\hline 6. & Kangra (Block Kangra) & Foli-6 & 32.29 \\
\hline 7. & Daulatpur (Block Kangra) & Foli-7 & 40.75 \\
\hline 8. & Nagri (Block Bhawarna) & Foli-8 & 10.25 \\
\hline 9. & Rajiana (Block Nagrota Bagwan) & Foli-9 & 42.00 \\
\hline 10. & Tikri (Block Nagrota Bagwan) & Foli-10 & 11.30 \\
\hline 11. & Malan (Block Nagrota Bagwan) & Foli-11 & 34.21 \\
\hline 12. & Palampur (Block Baijnath) & Foli-12 & 28.95 \\
\hline 13. & Utrala (Block Baijnath) & Foli-13 & 24.69 \\
\hline 14. & Mathrehar (Block Baijnath) & Foli-14 & 15.50 \\
\hline 15. & Baijnath (Block Baijnath) & Foli-15 & 12.15 \\
\hline \multirow[t]{2}{*}{16.} & Garla (Block Sullah) & Foli-16 & 32.55 \\
\hline & District Mandi:- & & \\
\hline 17. & Ahjoo (Block Chauntra) & Foli-17 & 22.45 \\
\hline 18. & Ladhruhin (Block Chauntra) & Foli-18 & 09.50 \\
\hline 19. & Chauntra (Block Chauntra) & Foli-19 & 14.34 \\
\hline 20. & Joginder Nagar(Block Drang) & Foli-20 & 15.25 \\
\hline 21. & Harabag (Block Drang) & Foli-21 & 48.20 \\
\hline 22. & Bhararoo (Block Drang) & Foli-22 & 07.36 \\
\hline 23. & Masoli (Block Drang) & Foli-23 & 43.88 \\
\hline 24. & Machial (Block Drang) & Foli-24 & 15.75 \\
\hline \multirow[t]{2}{*}{25.} & Balh (Block Drang) & Foli-25 & 13.60 \\
\hline & \multicolumn{3}{|c|}{ Location of samples procured from other parts of India } \\
\hline 26. & Raipur (Chhattisgarh) & Foli-26 & - \\
\hline 27. & Faizabad (Uttar Pradesh) & Foli-27 & - \\
\hline 28. & Gorakhpur (Uttar Pradesh) & Foli-28 & - \\
\hline 29. & Ludhiana (Punjab) & Foli-29 & - \\
\hline 30. & Kanpur (Uttar Pradesh) & Foli-30 & - \\
\hline 31. & Kaul (Haryana) & Foli-31 & - \\
\hline 32. & Kota (Rajasthan) & Foli-32 & - \\
\hline 33. & Jammu (Jammu \& Kashmir) & Foli-33 & - \\
\hline 34. & Gurdaspur (Punjab) & Foli-34 & - \\
\hline 35. & Mukeriyan (Punjab) & Foli-35 & - \\
\hline
\end{tabular}


Table.4.3 Variability in morphological characters of different isolates of Fusarium oxysporum f.sp. lini

\begin{tabular}{|c|c|c|c|c|c|c|}
\hline \multirow[t]{3}{*}{ Isolate } & \multicolumn{6}{|c|}{ Average size of conidia } \\
\hline & \multicolumn{3}{|c|}{ Macroconidia } & \multicolumn{3}{|c|}{ Microconidia } \\
\hline & $\begin{array}{c}(\mathbf{L})^{*} \\
(\mu \mathrm{m})\end{array}$ & $\begin{array}{l}(B)^{*} \\
(\mu \mathrm{m})\end{array}$ & No. of septa & $\begin{array}{c}(\mathbf{L}) \\
(\boldsymbol{\mu m})\end{array}$ & $\begin{array}{c}(\mathrm{B}) \\
(\mu \mathrm{m})\end{array}$ & No. of septa \\
\hline Foli-1 & 13.44 & 2.25 & $1-2$ & 5.52 & 2.34 & 0 \\
\hline Foli-2 & 15.81 & 2.56 & $1-2$ & 4.89 & 1.88 & 0 \\
\hline Foli-3 & 16.94 & 2.10 & $1-3$ & 9.20 & 2.64 & $0-1$ \\
\hline Foli-4 & 15.64 & 3.10 & $1-3$ & 8.53 & 2.95 & $0-1$ \\
\hline Foli-5 & 16.22 & 2.95 & $2-3$ & 5.29 & 2.59 & 0 \\
\hline Foli-6 & 29.53 & 2.62 & $2-4$ & 5.40 & 1.95 & 0 \\
\hline Foli-7 & 19.25 & 1.98 & $2-4$ & 6.33 & 1.99 & 0 \\
\hline Foli-8 & 14.96 & 2.59 & $1-2$ & 4.56 & 2.11 & 0 \\
\hline Foli-9 & 11.26 & 2.14 & $1-2$ & 4.45 & 2.96 & 0 \\
\hline Foli-10 & 24.61 & 2.81 & $1-4$ & 11.05 & 2.86 & $0-1$ \\
\hline Foli-11 & 31.31 & 2.57 & $1-3$ & 7.84 & 2.55 & $0-1$ \\
\hline Foli-12 & 15.19 & 2.22 & $1-3$ & 5.60 & 2.94 & 0 \\
\hline Foli-13 & 38.33 & 3.16 & $3-5$ & 11.19 & 2.36 & $1-1$ \\
\hline Foli-14 & 17.85 & 2.51 & $1-3$ & 7.51 & 2.73 & $0-1$ \\
\hline Foli-15 & 18.45 & 2.19 & $2-3$ & 6.26 & 2.82 & $0-1$ \\
\hline Foli-16 & 18.12 & 2.47 & $1-4$ & 8.49 & 2.61 & $0-1$ \\
\hline Foli-17 & 23.05 & 3.02 & $2-4$ & 8.12 & 1.95 & $0-1$ \\
\hline Foli-18 & 16.49 & 2.53 & $1-3$ & 6.47 & 2.77 & 0 \\
\hline Foli-19 & 12.34 & 2.91 & $3-4$ & 10.01 & 2.12 & $0-1$ \\
\hline Foli-20 & 36.90 & 2.42 & $1-3$ & 5.33 & 2.25 & $0-1$ \\
\hline Foli-21 & 23.23 & 2.81 & $1-3$ & 4.51 & 2.13 & 0 \\
\hline Foli-22 & 19.67 & 1.95 & $2-3$ & 7.26 & 2.80 & $0-1$ \\
\hline Foli-23 & 17.94 & 2.01 & $2-4$ & 6.44 & 2.51 & $0-1$ \\
\hline Foli-24 & 16.55 & 2.31 & $1-3$ & 7.55 & 2.95 & $0-1$ \\
\hline Foli-25 & 17.02 & 1.99 & $1-3$ & 6.14 & 2.22 & 0 \\
\hline Foli-26 & 15.29 & 2.34 & $1-3$ & 6.07 & 1.94 & 0 \\
\hline Foli-27 & 12.21 & 2.72 & $1-2$ & 4.81 & 1.75 & 0 \\
\hline Foli-28 & 16.30 & 2.95 & $1-4$ & 7.12 & 2.75 & $0-1$ \\
\hline Foli-29 & 17.62 & 2.31 & $2-4$ & 8.82 & 3.01 & $0-1$ \\
\hline Foli-30 & 34.29 & 2.79 & $2-4$ & 9.88 & 2.74 & $0-1$ \\
\hline Foli-31 & 14.66 & 2.81 & $1-3$ & 6.11 & 2.87 & $0-1$ \\
\hline Foli-32 & 19.37 & 2.76 & $2-4$ & 7.45 & 1.97 & $0-1$ \\
\hline Foli-33 & 19.78 & 2.53 & $2-4$ & 8.02 & 2.32 & $0-1$ \\
\hline Foli-34 & 28.95 & 2.64 & $1-4$ & 5.98 & 2.21 & 0 \\
\hline Foli-35 & 17.20 & 2.25 & $1-4$ & 7.43 & 2.69 & $0-1$ \\
\hline
\end{tabular}

L*= Length; $\mathrm{B} *=$ Breadth 
Table.3 Variability in cultural characters of different isolates of Fusarium oxysporum f.sp. lini

\begin{tabular}{|c|c|c|c|}
\hline Isolate & Colony colour & Pigmentation & $\begin{array}{c}\text { Colony diameter }(\mathrm{mm}) \\
\text { at } 9 \text { DAI }\end{array}$ \\
\hline Foli-1 & Cottony white & Light Pink & 78 \\
\hline Foli-2 & Purplish White & Purplish & 81 \\
\hline Foli-3 & Pale White & Absent & 79 \\
\hline Foli-4 & Purplish white & Absent & 75 \\
\hline Foli-5 & Purplish white & Light Pink & 79 \\
\hline Foli-6 & Purplish white & Purplish & 88 \\
\hline Foli-7 & Purplish white & Light Pink & 77 \\
\hline Foli-8 & Pale White & Brownish & 72 \\
\hline Foli-9 & Cottony white & Purplish & 73 \\
\hline Foli-10 & Cottony white & Purplish & 84 \\
\hline Foli-11 & Purplish White & Brownish & 90 \\
\hline Foli-12 & Cottony white & Absent & 76 \\
\hline Foli-13 & Pale White & Absent & 83 \\
\hline Foli-14 & Purplish white & Purplish & 76 \\
\hline Foli-15 & Pale White & Absent & 73 \\
\hline Foli-16 & Pale White & Purplish & 75 \\
\hline Foli-17 & Purplish White & Light Pink & 79 \\
\hline Foli-18 & Pale white & Purplish & 68 \\
\hline Foli-19 & Purplish white & Purplish & 79 \\
\hline Foli-20 & Purplish White & Light Pink & 75 \\
\hline Foli-21 & Cottony white & Absent & 73 \\
\hline Foli-22 & Pale White & Purplish & 76 \\
\hline Foli-23 & Pale White & Purplish & 74 \\
\hline Foli-24 & Purplish White & Purplish & 77 \\
\hline Foli-25 & Purplish white & Brownish & 90 \\
\hline Foli-26 & Purplish white & Purplish & 69 \\
\hline Foli-27 & Cottony White & Absent & 68 \\
\hline Foli-28 & Purplish White & Purplish & 72 \\
\hline Foli-29 & Pale White & Purplish & 89 \\
\hline Foli-30 & Purplish White & Purplish & 90 \\
\hline Foli-31 & Pale White & Absent & 78 \\
\hline Foli-32 & Purplish white & Purplish & 81 \\
\hline Foli-33 & Pale White & Purplish & 87 \\
\hline Foli-34 & Pale White & Light Pink & 80 \\
\hline Foli-35 & Purplish white & Absent & 82 \\
\hline
\end{tabular}


Plate.a Microscopic view of conidia of different isolates of Fusarium oxysporum f.sp. lini (macroconidia in circle \& microcondia in rectangle)
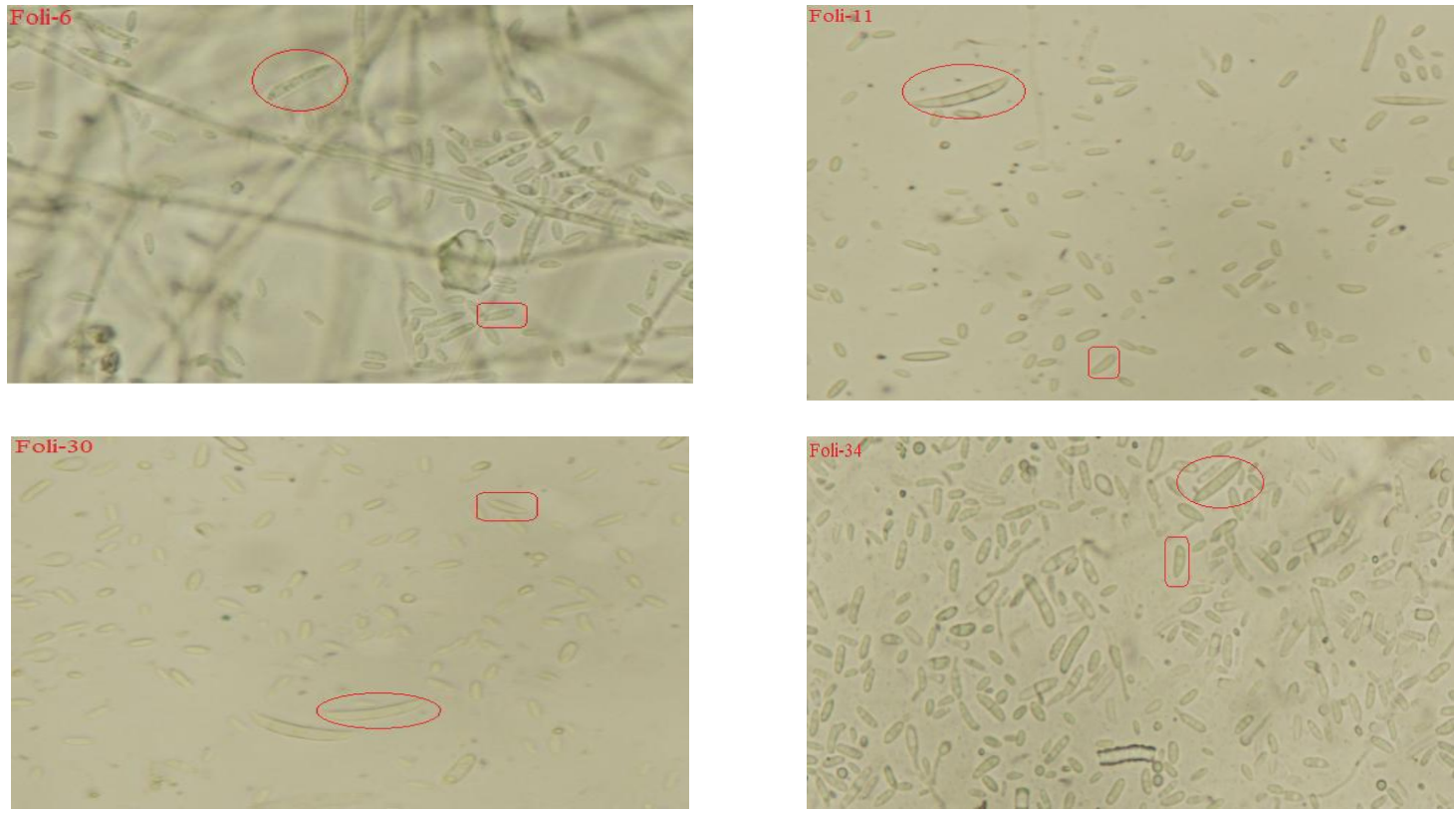

Plate.b Different Isolates of Fusarium oxysporum f.sp. lini (Foli-1 to Foli-35)

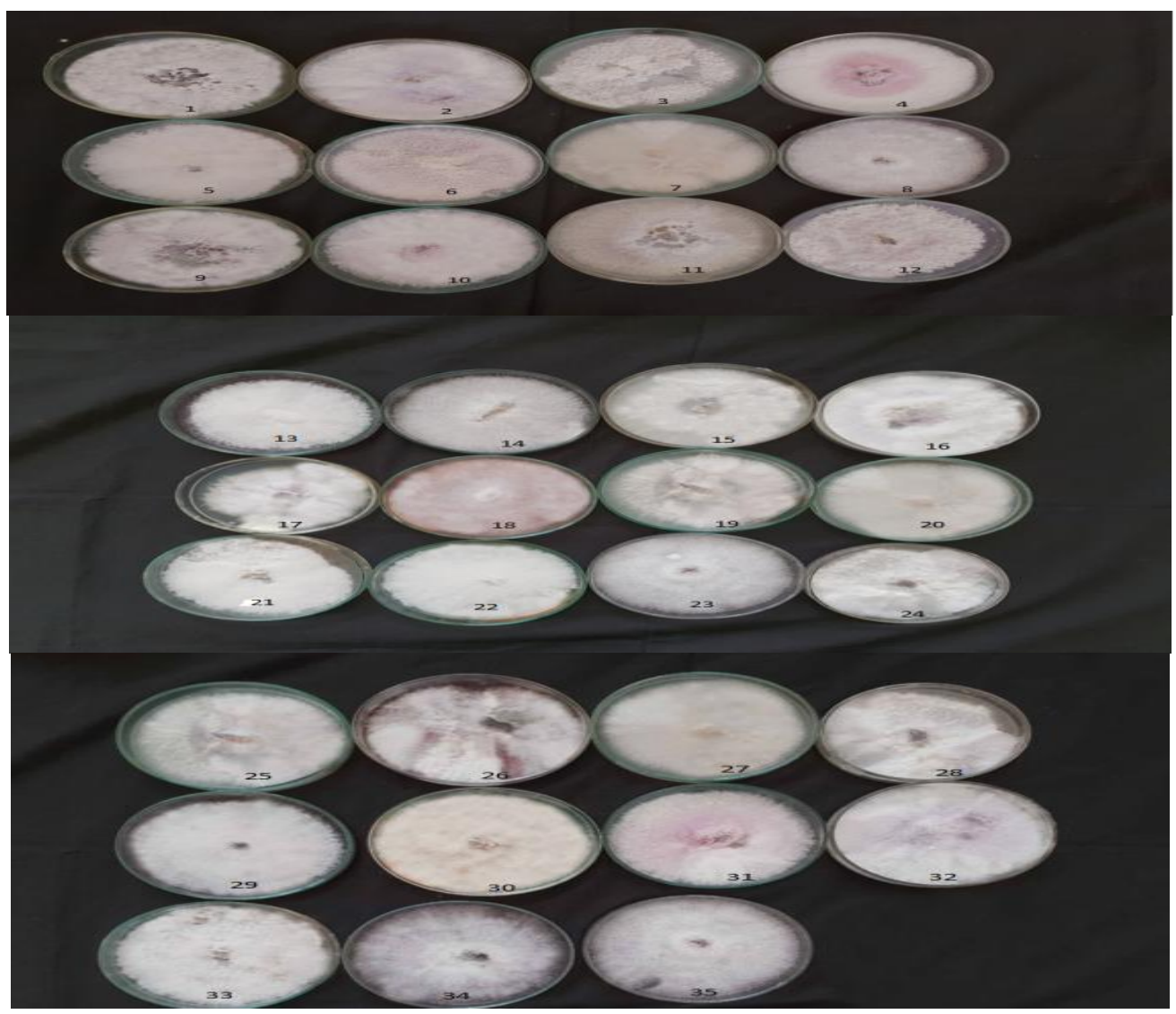


In conclusion Kommedahl et al., (1970) identified that isolates of Fusarium oxysporum f.sp. lini vary in: 1) morphology, with respect to the amount and type of sporulation, production of different types of conidia, size and number of septa and pigment production on growth media; 2) physiology, rate and type of growth on substrates and in host; 3) environmental preferences, antibiotic capabilities; and 4) pathogenicity. Therefore, it is considered an ideal pathogen to demonstrate diversity within a species. During the study it was concluded that all the 35 isolates of Fusarium oxysporum f.sp. lini exhibited considerable variations in cultural and morphological characters. In macroconidia, average length varied from $11.26 \mu \mathrm{m}$ in Foli-9 to $38.33 \mu \mathrm{m}$ in Foli-13 with 1-5 septa and average breadth varied from $1.95 \mu \mathrm{m}$ in Foli-22 to $3.16 \mu \mathrm{m}$ in Foli13.In microconidia, average length varied from $4.45 \mu \mathrm{m}$ in Foli-9 to $11.19 \mu \mathrm{m}$ in Foli13 with 0-1 septa and average breadth of varied from $1.75 \mu \mathrm{m}$ in Foli-2 to $3.01 \mu \mathrm{m}$ in Foli-29. Six isolates showed cottony white, 12 isolates showed pale white and17 isolates showed purplish white growth of culture. It was also concluded that the colony diameter ranged from 68.00 to $90.00 \mathrm{~mm}$ at $25 \pm 2^{\circ} \mathrm{C}$ for 9 days and fastest growing isolates were Foli-11, Foli-25 and Foli-30 with $90 \mathrm{~mm}$ of growth. Eleven isolates were fast growing, 21 isolates were medium growing and 3 isolates were slow growing.

\section{References}

Bolley, H.L. and Manns, T.F. 1932. Fungi of flaxseed and of flax-sick soil. Bulletin of North Dakota Agricultural Experiment Station: 259, 57

Booth, C. 1971. Fusarium - Laboratory guide to the identification of the major species. Canadian Journal of Plant Science. 73(1): 893-901

Burgess, L.W., Summerell, B.A., Bullock, S.,
Gott, K.P. and Bakhouse, D.1994. Laboratory manual of Fusarium research. University of Sydney and Botanic Garden, Sydney, Australia. $3^{\text {rd }}$ ed. pp.74.

Choi, Y.W., Hyde, K.D. and Ho, W.H. 1999. Single spore isolation of fungi. Fungal Diversity 3: 29-38

Dubey, S.C, Singh, S.R. and Singh, B. 2010. Morphological and pathogenic variability of Indian isolates of Fusarium oxysporum f.sp. ciceris causing chickpea wilt. Archives of Phytopathology and Plant Protection. 43(2): 174-190

Gill, K.S. 1967. Linseed. Publication and Information Division, New Delhi: ICAR

Gupta, S.K., Rana, S. and Jarial, K. 2011. Variation in morphological, cultural, pathological and molecular features of Fusarium oxysporum f.sp. pisi isolates causing wilt of pea (Pisum sativum L.). Journal of Mycology \& Plant Pathology. 41(2):275-278

Kishore, R., Pandey, M., Tripathi, U.K. and Singh, J. 2011. Evaluation of elite genotypes of linseed against Fusarium wilt. Indian Phytopathology. 64 (2): 203

Kommedahl, T., Christensen J.J. and Fredriksen, R.A. 1970. A half century of research in Minnesota on flax wilt caused by Fusarium oxysporum. Technical Bulletin of Agricultural Experiment Station: 273

Kripalini, N., Biswas, M.K. and Devi, P.S. 2018. Studies on morphological, cultural and pathogenic variability in isolates of Fusarium oxysporum f.sp. pisi causing wilt of pea from different districts of Manipur, India. International Journal of Current Microbiology and Applied Sciences. 7(11): 2500-2506

Luggar, O. 1890. A treatise on flax culture. 
Minnesota Agricultural Experiment Station Bulletin. 13: 5-21

Mayee, C.D. and Datar, V.V. 1986. Phytopathometry. Technical Bulletin1. MAU, Parbhani, India.: 119-120

Nath, N., Ahmed, A.U. and Aminuzzaman, F.M. 2017. Morphological and physiological variation of Fusarium oxysporum f.sp. ciceri isolates causing wilt disease in chickpea. International Journal of Environment, Agriculture and Biotechnology. 2: 201-212

Prameela, M., Rajeswari, B., Prasad, R.D. and Reddy, D.R.R. 2005.Variability in isolates of Fusarium oxysporum f.sp. carthami causing wilt of safflower. Indian Journal of Plant Protection. 33: 249-252

Saharan, G.S. and Mehta, N. 2002. Fungal diseases of linseed. Disease of Field crops, Indus Publishing company New Delhi. p 241

Wagh D.R. 2009. "Studies on variability and management of linseed wilt caused by Fusarium oxysporum f.sp. lini" M.Sc. Thesis, Department of Plant Pathology, College of Agriculture, Indira Gandhi Krishi Vishwavidyalaya Raipur (Chhattisgarh).p 5-31

\section{How to cite this article:}

Narinder Pal and Ashok Kumar. 2020. Variability in Morphological and Cultural Characters of Different Isolates of Fusarium oxysporum f.sp. lini. Int.J.Curr.Microbiol.App.Sci. 9(02): 844853. doi: https://doi.org/10.20546/ijcmas.2020.902.102 